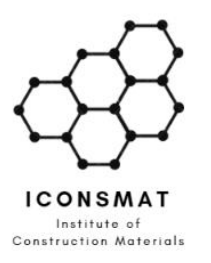

Content list available at ICONSMAT

Journal of Construction Materials

Journal homepage: $\underline{w w w . i c o n s m a t . c o m . a u / p u b l i c a t i o n ~}$
Article history:

Received 15 September 2020

Received in revised form

27 September 2020

Accepted 19 October 2020

Available online

10 November 2020

\title{
A Study of the Replacement of Natural Coarse Aggregate by Spherically-Shaped and Crushed Waste Cathode Ray Tube Glass in Concrete
}

\author{
N. N. M. Pauzi ${ }^{1 *}$, M. R. Karim², M. Jamil ${ }^{1}$, R. Hamid ${ }^{1}$, M. F. M. Zain ${ }^{1}$ \\ ${ }^{1}$ The National University of Malaysia \\ ${ }^{2}$ Dhaka University of Engineering \& Technology \\ *Corresponding Author: The National University of Malaysia, Bangi, 43600, Selangor, Malaysia; M: 6016-7524856; \\ E: nurulnoraziemah@gmail.com
}

\begin{abstract}
The aim of this study is to conduct an experimental investigation on the influence of complete replacement of natural coarse aggregate with spherically-shape and crushed waste cathode ray tube (CRT) glass to the aspect of workability, density, and compressive strength of the concrete. After characterizing the glass, a group of concrete mixes was prepared to contain a $40 \%$ spherical CRT glass and $60 \%$ crushed CRT glass as a complete $(100 \%)$ replacement of natural coarse aggregates. From a total of 16 types of concrete mixes, the optimum proportion was selected based on its best performance. The test results showed that the use of spherical and crushed glass that possesses a smooth surface, rounded, irregular and elongated shape, and low water absorption affects the workability of concrete. Due to a higher specific gravity of crushed glass, concrete mixes containing CRT glass had a higher density compared to ordinary concrete. Despite the spherical and crushed CRT glass being stronger than gravel, the results revealed a reduction in compressive strength of the concrete. However, using a lower water to binder $(\mathrm{w} / \mathrm{b})$ ratio and a higher superplasticizer (SP) dosage, it is found to enhance the compressive strength of $60.97 \mathrm{MPa}$ at 28 days that is lower by $13 \%$ than the control specimen. These findings indicate that waste CRT glass in the form of spherical and crushed could be used as an alternative of coarse aggregate that may pave the way for the disposal of hazardous e-waste.
\end{abstract}

DOI: 10.36756/JCM.v2.1.7 (C2020 Institute of Construction Materials

\section{Keywords}

Cathode ray tube, glass, coarse aggregate, compressive strength 


\section{Introduction}

CRT glass faces several issues that permit it to be disposed to landfill sites. Among the issues are the replacement of new technologies, the high concentration of heavy metals, non-biodegradable nature of the CRT glass and their limited life in the forms in which they are produced [1], [2]. The high concentration of heavy metals, especially lead $(\mathrm{Pb})$ metals contained in the CRT glass in the neck and funnel part, have posed higher risks to human health and the environment, thus in the year 2005, it was classified as scheduled e-wastes under Malaysia Environmental Quality Regulations [2]. The recycling of a large amount of CRT glass waste was deemed necessary not only due to the potential of heavy metal leached at the landfill sites, but also because of the quantity of CRT waste was expected to increase in years to come [3].

Past studies have extensively investigated the use of waste CRT glass as a replacement of natural resources in the production of mortar and concrete [4]-[9]. Most of them reported that the chemical composition of the glass, particle size, shape, types and percentage replacement give a significant impact to the concrete and mortar performance. According to Maschio et al. [4], the crushing of the glass to about the particle size of cement (micro-scale) can contribute to the forming of calcium silicate hydrate ( $\mathrm{C}-\mathrm{S}-\mathrm{H})$ gel, which enables the improvement of concrete strength. Besides that, past studies indicated that the crushing of glass into a size smaller than $4.75 \mathrm{~mm}$ for use as a fine aggregate at various percentage replacements up to $100 \%$ has shown that the strength exceeds the control sample [4], [7], [10], [11]. The increase in concrete strength may be attributed to the shape of glass that has angular grain shape than sand [10]. However, there are also past studies that reported a reduction in concrete strength as the content of glass sand increase [5], [6], [8], [12]. It is mainly due to the smoothness of the glass surface that weakens the bonding between aggregate and cement paste.

As discussed above, a number of research works have been conducted to examine the effects of using waste CRT glass as partial and complete replacement of cement and fine aggregate on the concrete performance. The use of CRT glass as construction materials enables the preservation of natural resources and the total of carbon emissions could be reduced [3]. In deed, there are several other ways to reduce the carbon foot print of concrete production such as use of recycled aggregate, automation and $\mathrm{CO}_{2}$ capture [48-67], however, the current study focuses only on the use of glass in concrete. To the authors' knowledge, there is lack of information on the production of concrete made with spherical glass as coarse aggregate. Therefore, the aim of this research was to investigate the effects of spherically-shaped and crushed CRT glass as a complete replacement of natural coarse aggregates in the production of a high strength concrete.

\section{Materials and Methodology}

\section{A. Materials}

Ordinary Portland cement (OPC), type $1(42.5 \mathrm{~N})$ and silica fume were used as cementitious material in this study. The silica fume meets the requirements of ASTM C1240 [13], with bulk density of $481 \mathrm{~kg} / \mathrm{m} 3$ and specific gravity of 2.2. In addition, polycarboxylate ether superplasticizer (SP) admixture (RPF 2000) was used to highly reduce the mixing water and it meets the requirements of ASTM C494 [14]. The standard sand in accordance with ASTM C33 [14] was used as a fine aggregate, and its fineness modulus is 2.81 .

In this study, waste CRT glass was used as a complete replacement of natural coarse aggregate. The CRT glass was formed into two different shapes which are rounded and irregular shape. It was supplied 
by the company of Nippon Electric Glass Malaysia (NEGM). The spherical glass was made through melting, annealing and cooling process that forms a rounded shape of glass, while the crushed shape of glass was made through smashing and grading to form an irregular shape glass. The maximum size of coarse aggregate is $20 \mathrm{~mm}$. Figs. 1 (a) and (b) shows the CRT glass used as coarse aggregates in this study. The coarse aggregates were tested in accordance with the standards for identified their physical and mechanical properties.

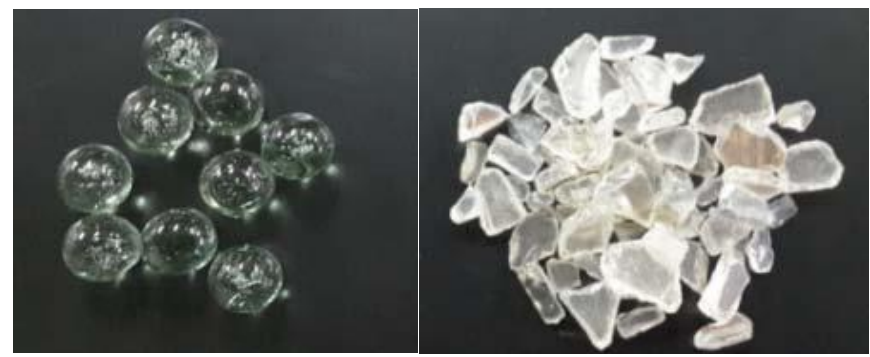

Figure 1 (a) The spherically shaped of CRT glass as coarse aggregate used in this study. (b) The crushed CRT glass as coarse aggregate used in this study.

\section{B. Mix Proportion of Materials}

The concrete mix proportion was designed by taking into consideration the properties of spherical and crushed glass. The material proportions of the different glass concrete mix are presented in Table II, and were altered based on trial and error to achieve the adequate workability and strength. The cementitious content used in this study was made using $90 \%$ OPC and $10 \%$ silica fume. For all mixes of glass concrete, the coarse aggregate ratio of $40 \%$ spherical glass and $60 \%$ crushed glass was used. Meanwhile, the control sample was prepared using $100 \%$ gravel as coarse aggregate.

\section{Tests on Materials}

In order to understand the properties of spherically shaped and crushed CRT glass that were proposed in this study, a series of physical and mechanical tests were conducted, as shown in Table II. Besides, the applicability of CRT glass as a complete replacement of coarse aggregate in concrete production was examined through compressive strength and lead leaching test. 
Table 1 Material proportions weights per unit volume

\begin{tabular}{cccccccc}
\hline \multirow{2}{*}{ Mixture code } & w/b ratio & Cementitious & Sand & \multicolumn{2}{c}{ Coarse aggregate } & Water & SP \\
\cline { 1 - 1 } C1-SP2.0 & 0.35 & 490 & 582 & 1115 & - & 171 & 2.0 \\
G1-SP2.0 & 0.35 & 490 & 582 & - & 1115 & 171 & 2.0 \\
G1-SP2.5 & 0.35 & 429 & 688 & - & 1115 & 150 & 2.5 \\
G1-SP3.0 & 0.35 & 429 & 688 & - & 1115 & 150 & 3.0 \\
C2-SP2.0 & 0.33 & 519 & 557 & 1115 & - & 171 & 2.0 \\
G2-SP2.0 & 0.33 & 519 & 557 & - & 1115 & 171 & 2.0 \\
G2-SP2.5 & 0.33 & 454 & 666 & - & 1115 & 150 & 2.5 \\
G2-SP3.0 & 0.33 & 454 & 666 & - & 1115 & 150 & 3.0 \\
C3-SP2.0 & 0.30 & 571 & 514 & 1115 & - & 171 & 2.0 \\
G3-SP2.0 & 0.30 & 571 & 514 & - & 1115 & 171 & 2.0 \\
G3-SP2.5 & 0.30 & 500 & 628 & - & 1115 & 150 & 2.5 \\
G3-SP3.0 & 0.30 & 500 & 628 & - & 1115 & 150 & 3.0 \\
C4-SP2.0 & 0.29 & 591 & 497 & 1115 & - & 171 & 2.0 \\
G4-SP2.0 & 0.29 & 591 & 497 & - & 1115 & 171 & 2.0 \\
G4-SP2.5 & 0.29 & 517 & 613 & - & 1115 & 150 & 2.5 \\
G4-SP3.0 & 0.29 & 517 & 613 & - & 1115 & 150 & 3.0 \\
\hline \hline
\end{tabular}

\section{Results and Discussion}

\section{A. Characterization of Coarse Aggregates}

Particle size distribution curve of crushed glass and gravel are presented in Fig. 2. It can be seen that crushed glass generally shows a higher content of finer material than gravel. Meanwhile, spherical glass has a uniform size of $19 \mathrm{~mm}$. The spherical glass is considered as gap-graded aggregates as it consists of only one size of coarse aggregate with all the fine aggregates, and cement paste passes through the voids in the concrete mixes. 


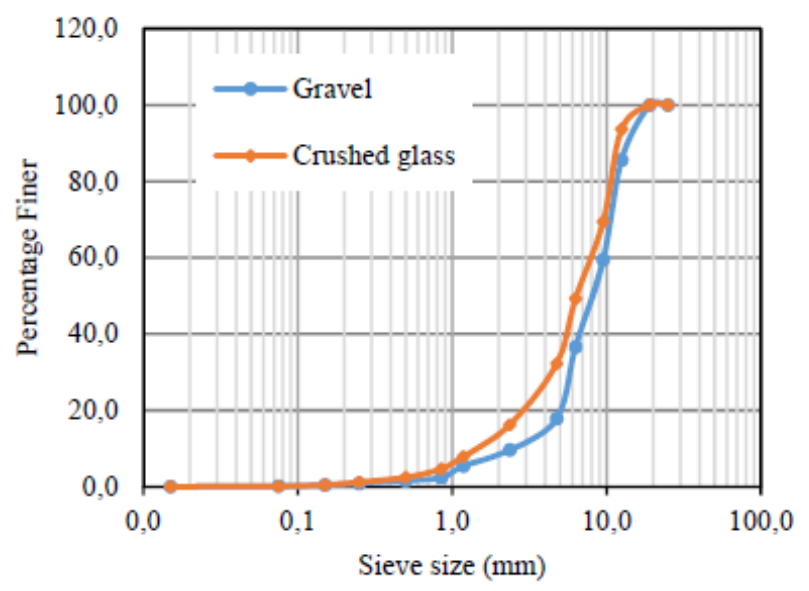

Figure 2 Particle size distributions curve

Table III presents the physical and mechanical properties of spherical glass, crushed glass, and natural coarse aggregate (gravel). In designing the proportion of concrete mixes, it is necessary to determine the specific gravity and water absorption of the use aggregates. As seen in Table III, crushed glass is much heavier than spherical glass and gravel with a specific gravity of 2.67 . While the percentage absorption for both of the glass are nearly to zero, which were lower than gravel. It indicated that the glass has less potential of absorption of water in the pore spaces within the glass particles, compared to the gravel. According to ACl E1-99 [23], the most normal weight aggregates have relative densities lying between 2.30 and 2.90 with percentage absorption from 0 to $8 \%$. Besides that, the value of the aggregate density affects the design of concrete mix proportion and their density [24], [25]. Crushed glass has the highest bulk density with respect to spherical glass and gravel, and they are still under the range of normal weight coarse aggregate as its bulk density ranges from 1280 to $1920 \mathrm{~kg} / \mathrm{m}^{3}$ [23]. On the other hand, the uniform size of spherical glass causes it to have the highest percentage void of $42 \%$. Test results also show that crushed glass and gravel were not considered as the flaky aggregate. Based on the study of Neville [26], the flakiness index of natural gravel is $50 \%$, while for crushed or partially crushed aggregate it is $40 \%$. But, the elongation index of crushed glass and gravel is higher than $15 \%$, which is considered undesirable. It has the length larger than its width. The elongated aggregate requires more water to produce a workable concrete than rounded aggregate [26]. The ideal aggregate shape should be angular and crushed with a minimum of flat and elongated particles [25]. The spherical glass is considered as the rounded aggregate that is not flaky and elongated.

Table 2 List of experimental tests

\begin{tabular}{|c|c|c|}
\hline Testing & Description & References \\
\hline \multicolumn{3}{|c|}{ Physical properties of spherical and crushed glass } \\
\hline Sieve analysis & $\begin{array}{l}\text { Variations in grading can affect the homogeneity of } \\
\text { concrete mixture }\end{array}$ & [15] \\
\hline Specific gravity & $\begin{array}{l}\text { Understanding the relative density and weight of the } \\
\text { spherical and crushed glass }\end{array}$ & {$[16]$} \\
\hline
\end{tabular}


Absorption

Flakiness and elongation
Shown the change of the mass of glass due to the absorption of water in the pore spaces within the particles, compared to the dry condition.

Indicating the mass of glass and the voids between particles to fill a container of a specified unit volume.

Measuring the length, width and thickness of the spherical and crushed glass using a specified caliper.

Mechanical properties of spherical and crushed glass

\begin{tabular}{ccc}
\hline $\begin{array}{c}\text { Aggregate crushing value } \\
\text { Aggregate impact value }\end{array}$ & $\begin{array}{c}\text { Examining the resistance of spherical and crushed glass } \\
\text { to a gradual increase of compressive load. } \\
\text { Determining the resistance of spherical and crushed } \\
\text { glass to impact loading. }\end{array}$ & {$[19]$} \\
\hline Concrete properties & {$[19]$} \\
Slump & $\begin{array}{c}\text { Identifying the workability of the fresh concrete } \\
\text { mixtures. }\end{array}$ & {$[21]$} \\
Cinding the density of fresh concrete mixture. & [22] \\
\hline \hline
\end{tabular}

Spherical glass has the lowest crushing value followed with crushed glass and gravel. The low ACV indicated that the glass is stronger than gravel as it has the lesser amount of material that was crushed and breaks into smaller pieces under a gradual increase of compressive load. In addition, the glass aggregates could be used in the surface layer of road construction as the crushing value does not exceed 30\% [19]. Meanwhile, the impact values of the glass and gravel had confirmed the ability of aggregates to sudden shock since the percentage of fines produced from the samples after exposing to a sudden shock or impact is less than $20 \%$ [19].

\section{B. Workability of Fresh Concrete}

Figs. 3 and 4 present the slump values of four groups of concrete mixtures. As seen in Fig. 3, the slump values for all the specimens of glass concrete mixes increase up to $40 \%$ compared to the control specimens. The combined use of glass at level $40 \%$ of spherical glass and $60 \%$ of crushed glass as $100 \%$ replacement of natural coarse aggregate has significantly increased the workability of concrete mixtures compared to control samples. These results suggest that the inclusion of glass as coarse aggregate affecting the workability of the mixture can be related to the physical properties of the glass. The physical properties of spherical and crushed glass having a smoother surface, rounded and irregular shape, and low water absorption had resulted in a major increase of slump values. In addition, past studies [27]-[28] reported that the higher the replacement levels of CRT glass as aggregates causing the increase of the mixture workability, just as in this study adopted a 100\% replacement. Besides that, Fig. 
3 also revealed that with the increasing of $\mathrm{w} / \mathrm{b}$ ratio, the slump value of the concrete mixes increased. According to IS 456 [29], the slump values of mixes with w/b ratio of 0.30 (G3-SP2.0) and w/b ratio of 0.29 (G4-SP2.0) fall into the category of 'high' workability which is in the range from 100 to $150 \mathrm{~mm}$. However, for glass concrete mixes with w/b ratio of 0.35 (G1- SP2.0) and w/b ratio of 0.33 (G2-SP2.0), it was found that these mixes fall into the category of 'very high' workability, the prescribed range is more than $150 \mathrm{~mm}$. In the case of 'very high' workability, the determination of flow is more appropriate to measure the workability of the mixture [29]. The increase in the slump value due to the increased of $\mathrm{w} / \mathrm{b}$ ratio was also reported in several past studies [25], [30], [31].

Table 3 Properties of coarse aggregate used in this study

\begin{tabular}{|c|c|c|c|c|}
\hline Properties & Unit & Gravel & Spherical glass & Crushed glass \\
\hline \multicolumn{5}{|c|}{ Physical properties } \\
\hline Size & $\mathrm{mm}$ & 4.75 to 20 & 20 & 4.75 to 20 \\
\hline Specific gravity & & 2.64 & 2.61 & 2.67 \\
\hline Unit weight & $\mathrm{Kg} / \mathrm{m}^{3}$ & 1539 & 1527 & 1555 \\
\hline Absorption & $\%$ & 0.40 & 0.02 & 0.05 \\
\hline Void & $\%$ & 40.98 & 41.38 & 42.03 \\
\hline Flakiness & $\%$ & 23 & & 15 \\
\hline Elongation & $\%$ & 21 & & 16 \\
\hline Surface texture & & Rough & Smooth & Smooth \\
\hline \multicolumn{5}{|c|}{ Mechanical properties } \\
\hline Crushing value & $\%$ & 24.34 & 16.98 & 20.33 \\
\hline Impact value & $\%$ & 14.66 & & 19.35 \\
\hline
\end{tabular}

Furthermore, the effects of SP dosage to the slump value of concrete mixture containing spherical and crushed CRT glass as coarse aggregates are presented in Fig. 4 . The results show that the slump value of glass concrete mixes increases gradually as the percentage of SP dosage increases from $2 \%$ to $3 \%$ of the cementitious content. It can be seen in sample G4- SP2.0, G4-SP2.5 and G4-SP3.0 as the slump value are $135 \mathrm{~mm}, 154 \mathrm{~mm}$ and $172 \mathrm{~mm}$, respectively. 


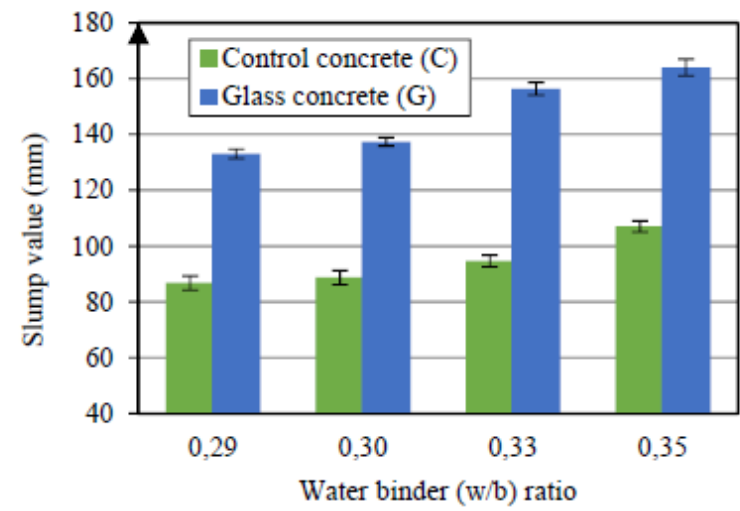

Figure 3 Slump values of fresh concrete at different w/b ratio, but constant superplasticizer dosage of $2 \%$.

In this study, the benefits of using high dosage of polycarboxylate ether SP as a water reducing agent can be seen.

According to Santos et al. [32], the use of polycarboxylate ether SP is capable of producing more workable concrete, more resistant to segregation, and also gives the potential to reduce the water content up to $40 \%$. Besides, the use of silica fume as mineral admixture has increased the water demand of the mixture. The finer particle size of silica fume which means having a larger surface area than any other cementitious material like fly ash caused more water being absorbed [25], [32].

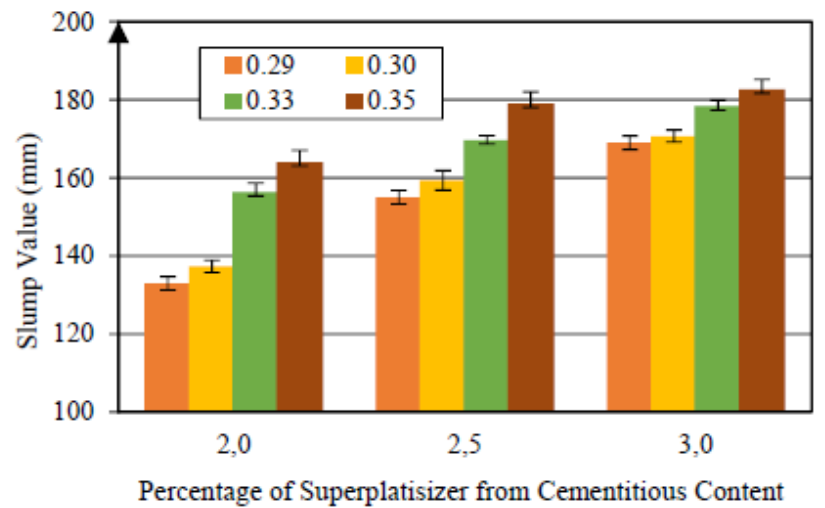

Figure 4 Slump values of fresh concrete at different percentage of superplasticizer.

\section{Density}

Fig. 5 shows the density of all four groups of concrete mixtures where each of them has a different $w / b$ ratio and SP dosage. The concrete mixture containing spherically shaped and crushed glass as coarse aggregate, namely as mix $\mathrm{G}$ has slightly higher density around $2 \%$ than control specimens, mix C. It can be seen by comparing the density of specimens G4- SP2.0 and specimens C4-SP2.0 that it has slightly higher density at $2321 \mathrm{~kg} / \mathrm{m}^{3}$ than $2285 \mathrm{~kg} / \mathrm{m}^{3}$, respectively. This was attributed to the higher specific gravity of crushed glass compared to natural coarse aggregates.

Besides that, the density of concrete was observed to decrease when a low amount of $\mathrm{w} / \mathrm{b}$ ratio used in the mixture, as shown in Fig. 5. According to the specimens which have different $\mathrm{w} / \mathrm{b}$ ratios but have the same SP dosage, the specimens with $\mathrm{w} / \mathrm{b}$ ratio 0.35 (G1-SP2.5) have a higher density at $2386 \mathrm{~kg} / \mathrm{m}^{3}$ than specimens with w/b ratio 0.29 (G4- SP2.5), that is only at $2338 \mathrm{~kg} / \mathrm{m}^{3}$. Also, it is clear from Fig. 5 that regardless of the aggregate type which is whether glass or natural rock, the use of a high amount 
of SP which is from $2 \%$ to $3 \%$ of cementitious content has increased the unit weight of the concrete mixture.

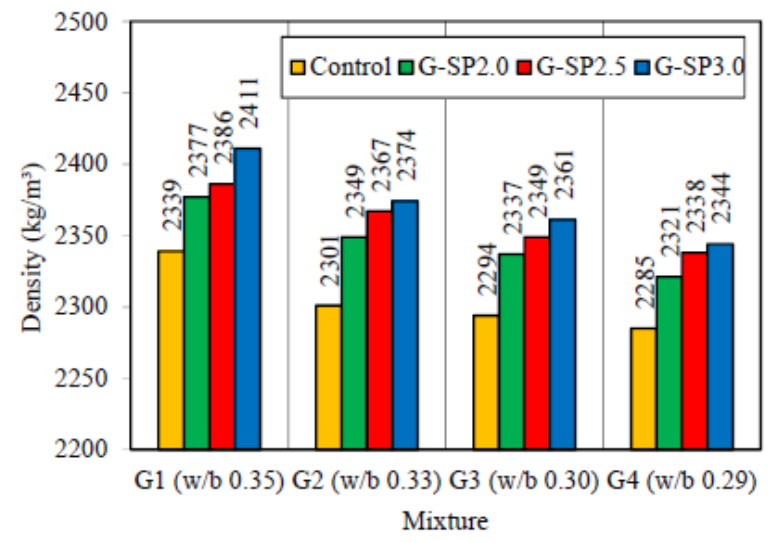

Figure 5 Density of fresh concrete at different $\mathrm{w} / \mathrm{b}$ ratio and SP dosage

\section{Compressive Strength}

The compressive strength for all four groups of concrete mixtures was shown in Figs. 6-9. The results clearly showed that the compressive strength increases by extending the curing time from 7 days to 28 days. According to $\mathrm{ACl} 363 \mathrm{R}$, the common curing time for compressive strength development is at the age of 28 days for the concrete to receive the load or maximum stress [25].

Among the four groups of concrete mixes, specimens mix G4-SP3.0 shows the nearest strength to control mix C4-SP2.0 at age 28 days, as shown in Fig. 6. The compressive strength of sample mix G4SP3.0 that was designed with the use of spherical and crushed glass as coarse aggregate, $\mathrm{w} / \mathrm{b}$ ratio 0.29 and amount of SP, 3\% from cementitious content, has significantly less by $13 \%$ than control mix C4SP2.0, which is $60.97 \mathrm{MPa}$ and $70.10 \mathrm{MPa}$, respectively.

The reduction value of compressive strength could be attributed by the vertical cracking in the specimens that were subjected to compression, which depends largely on the properties of coarse aggregate. The use of glass material that has a smooth surface instead of natural rock as coarse aggregate causes the decrease of bonding strength between the aggregates and cement paste, leads to the cracking at lower stress compared to rough and angular aggregate [33]-[37]. According to ACl $363 R$ [25], the mechanicals bonds are influenced by the surface and shape properties of coarse aggregate.

Figs. 6-9 plotted the compressive strength versus curing ages that were categorized based on the $\mathrm{w} / \mathrm{b}$ ratio. Among the four $\mathrm{w} / \mathrm{b}$ ratios i.e. $0.35,0.33,0.30$ and 0.29 , concrete specimens that were designed with $\mathrm{w} / \mathrm{b}$ ratio 0.29 have the highest strength, as indicated in Fig. 6 . The reduction of compressive strength with the increase of $\mathrm{w} / \mathrm{b}$ ratio can be seen in the concrete specimens with $\mathrm{w} / \mathrm{b}$ ratio 0.29 (mix G4-SP2.0), w/b ratio 0.30 (mix G3-SP2.0) and w/b ratio 0.33 (G2-SP2.0), of 58.14 MPa, 49.97 MPa, and $49.81 \mathrm{MPa}$, at 28 days, respectively. It is well recognized that concrete strength is affected by the content of water to the cementitious material.

Concrete mixes with a lower content of $\mathrm{w} / \mathrm{b}$ ratios have a higher paste volume. Thus, the mixes have a better uniformity and good packing density than those with high w/b ratios [38], [39]. According to Wongkornchaowalit [40], the excessive water content will cause an inappropriate consistency. Therefore, the use of rounded shape and low water absorption of spherical and crushed glass as coarse 
aggregate and a higher amount of SP enables to reduce mixing water requirement up to $30 \%$ but still has the abilities to increase flowability and consistency of mixture, less compaction and producing denser concrete. Therefore, the incorporating of this material makes it possible to use a low $\mathrm{w} / \mathrm{b}$ ratio to achieve a higher strength. Moreover, as illustrated in Fig. 9, the compressive strength of the glass concrete mixtures (G1) and control concrete mixtures (C1) are made up with the same w/b ratio, 0.35 and different amount of SP. Samples mix G1-SP2.0, G1-SP2.5, and G1-SP3.0 contain a different amount of $\mathrm{SP}$, which are from $2 \%$ to $3 \%$ of the cementitious content. It can be observed that the sample mix G1-SP3.0 with 3\% SP showed the largest reduction in compressive strength, compared with the control $\operatorname{mix}$ C1-SP2.0.

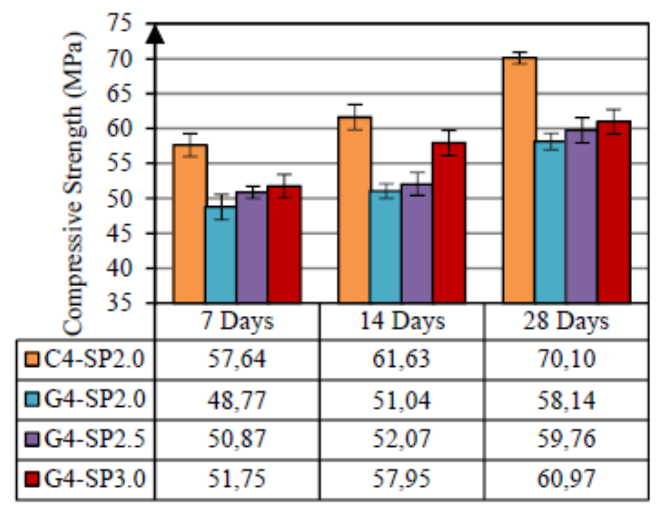

Figure 6 Compressive strength development of water binder ratio, 0.29 with different percentage of superplasticizer.

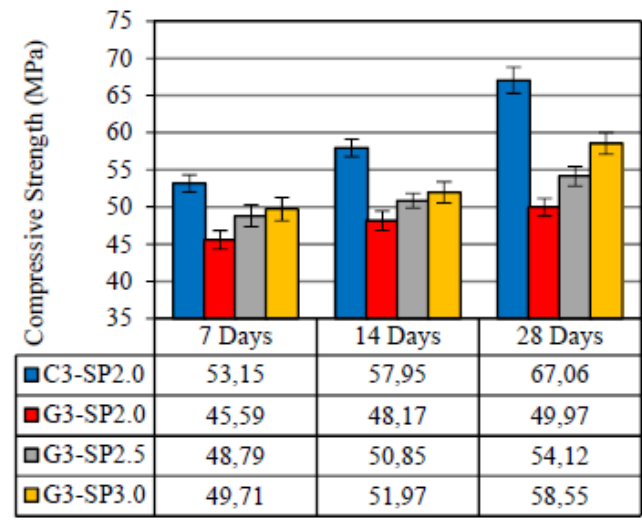

Figure 7 Compressive strength development of water binder ratio 0.30 with different percentage of superplasticizer. 


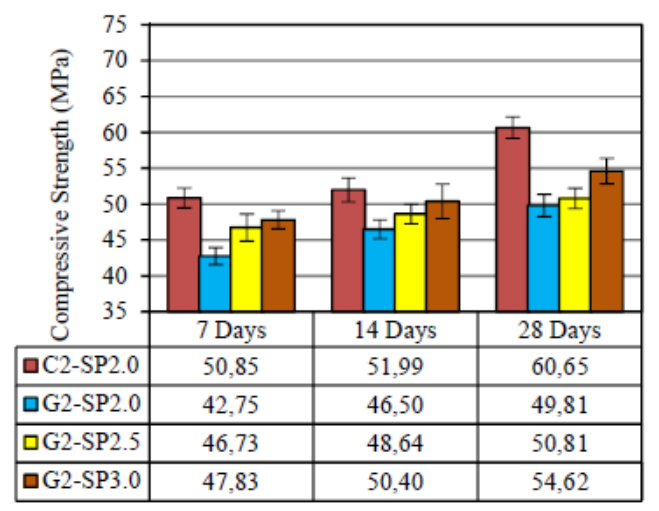

Figure 8 Compressive strength development of water binder ratio 0.33 with different percentage of superplasticiser

The reduction of compressive strength in specimens G1-SP3.0 is due to the appeared of bleeding of mixing water from the freshly mixed concrete G1-SP3.0. The mixing water from the concrete surface was evaporated rapidly, resulting in the shrinkage cracks. Besides that, the reduction of concrete strength was attributed by the use of high $\mathrm{w} / \mathrm{c}$ ratio $(0.35)$ and SP dosage (3\% of cementitious content) causing the paste too dilute to gain its strength. On the other hand, Figs. 6-8 indicated that the increasing of SP dosage in glass concrete specimens gives a higher increase of compressive strength. It can be seen that the strength difference between the glass concrete specimens (G) with SP dosage 3\%, i.e. mix G2-SP3.0, G3-SP3.0 and G4-SP3.0 with their control specimens of 2\% SP dosage becomes smaller. Besides, the mixture of glass concrete with $\mathrm{w} / \mathrm{b}$ ratio in between 0.33 to 0.29 , did not show tendencies to segregate or bleed. It is suggested that for the glass concrete specimens, the trend of the increased compressive strength with the increase of SP dosage, can be explained as the use of high dosage of SP causes a wider spread of the cementitious particles in the mixture [41], [42]. Similar observations were also reported in few of the previous studies [32], [41]-[43]. Therefore, the concrete containing spherical and crushed glass as a complete replacement of natural gravel could achieve a comparable strength with the normal specimens, but only if an adequate amount of water and SP dosage were used.

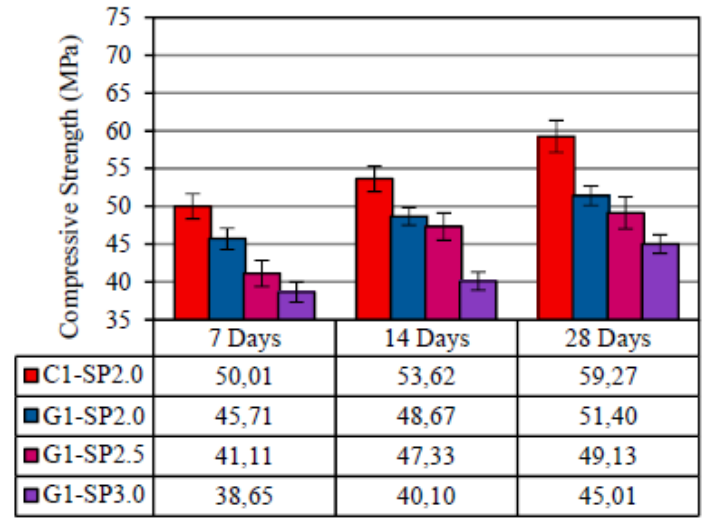

Figure 9 Compressive strength development of water binder ratio 0.35 with different percentage of superplasticizer. 


\section{E. Visual Inspection}

The magnified images of the concrete surface containing spherical and crushed glass as coarse aggregate are shown in Fig. 10. The spherical and crushed glass could be seen undamaged due to a higher strength of the material, as shown by the orange lines. The authors [27], [44], [45] claimed that the use of crushed CRT glass as a fine aggregate can cause the concrete expansion due to the alkalisilica reaction (ASR). Besides that, several past studies [5], [9], [11], [46], [47] reported that the lead $\mathrm{Pb}$ ) leaching of hardened mortar containing CRT glass as fine aggregates is higher than the allowable limit $(5 \mathrm{mg} / \mathrm{L})$, meaning that it carries a high risk of lead $(\mathrm{Pb})$ metal release which can harm the environment and the human body. Therefore, it is expected that the use of undamaged and larger sizes of spherical and crushed glass as coarse aggregate could lower the probability of lead (Pb) metal leached and concrete expand due to ASR, as there will be no inclusion of any chemical compounds from the CRT glass to the concrete mixture.

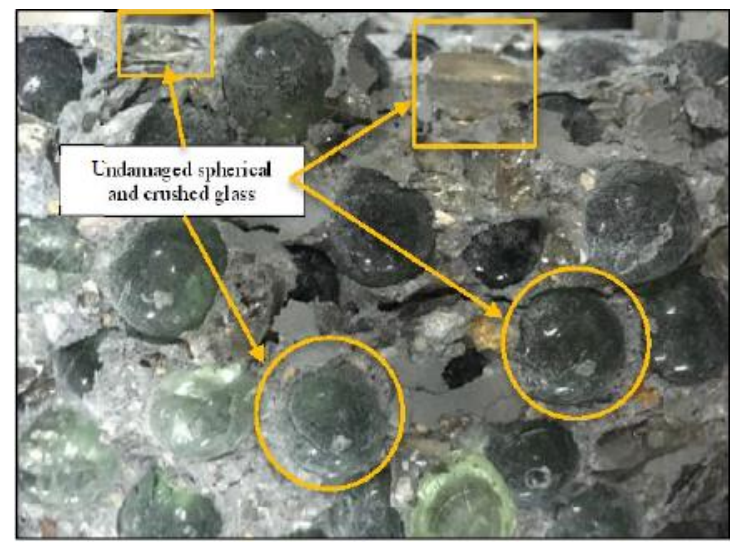

Figure 10 The fracture surface appearance of concrete with spherical and crushed glass as coarse aggregate

\section{Conclusion}

Based on the experimental results, the following conclusions can be drawn:

1) Spherical and crushed glass possesses a smooth surface, rounded and irregular shape, elongated shape, a higher density, and less water absorption compared to natural rock as coarse aggregate.

2) The used of glass with a smooth surface texture, rounded shaped of spherical glass and irregular shaped of crushed glass as coarse aggregates has allowed the used of lower w/c ratio, and can still maintain the given workability level. Slump value of glass concrete samples was found to be increased up to $40 \%$ and fell in the category of 'high' workability which is in the range from 100 to $150 \mathrm{~mm}$.

3) Concrete samples containing glass aggregate showed a higher density of $6 \%\left(\right.$ e.g. $2569 \mathrm{~kg} / \mathrm{m}^{3}$ ) than control specimens. Concrete density increases with the increasing amount of SP percentage.

4) Replacing gravel with spherical and crushed glass causes the reduction value of compressive strength. However, the gap of compressive strength between glass concrete specimens and control specimens can be lowered by decreasing the $\mathrm{w} / \mathrm{b}$ ratio and increase the SP dosage.

5) The optimum mix proportion was found on specimens G4-SP3.0 that was designed with a cement content of $465 \mathrm{~kg} / \mathrm{m}^{3}$, silica fume $52 \mathrm{~kg} / \mathrm{m}^{3}, w / \mathrm{b}$ ratio 0.29 and $3 \%$ SP from cementitious content which provided the highest compressive strength among other glass concretes at 65.97 MPa. 
6) Based on the overall findings, CRT glass in the form of spherically shaped and crushed form could be used as a potential alternative to replace the natural rock as a coarse aggregate, which not only can fulfill the needs of managing the hazardous waste but also can impart a "green" concept to the concrete industry.

\section{Acknowledgement}

This research was part of the project, "Application of Waste CRT Glass as Aggregate in HighPerformance Concrete", supported by Nippon Electric Glass Malaysia (NEGM). The authors acknowledge their ample gratefulness to Almighty for being able to complete this paper. Above all, the authors would like to appreciate highly the administration of University Kebangsaan Malaysia (UKM) for providing financial support of research grant scheme (AP-2015-002). The second author expresses a deep acknowledgment to Dhaka University of Engineering \& Technology, Gazipur, Bangladesh.

\section{References}

[1] Q. Xu, G. Li, W. He, J. Huang, X. Shi, "Cathode ray tube (CRT) recycling: current capabilities in China and research progress," Waste Manag., vol. 32, pp. 1566-1574, Apr. 2012.

[2] V. B. Kreng, H. T. Wang, "A technology replacement model with variable market potential - an empirical study of CRT and LCD TV," Technol. Forecast. Soc. Change, vol. 76, pp. 942-951, Feb. 2009.

[3] A. M. Rashad, "Recycled cathode ray tube and liquid crystal display glass as fine aggregate replacement in cementitious materials," Constr. Build. Mater., vol. 93, pp. 1236-1248, May 2015.

[4] S. Maschio, G. Tonello, E. Furlani, "Recycling glass cullet from waste crts for the production of high strength mortars," J. Waste Manag., vol. 2013, pp. 1-8, May 2013.

[5] T.-C. Ling, C.-S. Poon, "Use of CRT funnel glass in concrete blocks prepared with different aggregateto-cement ratios," Green Mater., vol. 2, pp. 43-51, Mar. 2014.

[6] T. Ling, C. Poon, "Use of recycled CRT funnel glass as fine aggregate in dry-mixed concrete paving blocks," J. Clean. Prod., vol. 68, pp. 209-215, Jan. 2014.

[7] P. Walczak, J. Małolepszy, M. Reben, K. Rzepa, "Mechanical properties of concrete mortar based on mixture of crt glass cullet and fluidized fly ash," Procedia Eng., vol. 108, pp. 453-458, 2015.

[8] J. Li, M. Guo, X. Qiang, C.S. Poon, "Recycling of incinerated sewage sludge ash and cathode ray tube funnel glass in cement mortars," J. Clean. Prod., Mar. 2017.

[9] H. Zhao, C. S. Poon, "A comparative study on the properties of the mortar with the cathode ray tube funnel glass sand at different treatment methods," Constr. Build. Mater., vol. 148, pp. 900-909, May 2017.

[10] D. Romero, J. James, R. Mora, C.D. Hays, "Study on the mechanical and environmental properties of concrete containing cathode ray tube glass aggregate," Waste Manag., vol. 33, pp. 1659-1666, Apr. 2013.

[11] T. C. L. Hui Zhao, Chi Sun Poon, "Properties of mortar prepared with recycled cathode ray tube funnel glass sand at different mineral admixture," Constr. Build. Mater., vol. 40, pp. 951-960, Nov. 2013.

[12] G. Sua-iam, N. Makul, "Use of limestone powder during incorporation of Pb-containing cathode ray tube waste in self-compacting concrete," J. Environ. Manage., vol. 128, pp. 931-940, Jul. 2013. 
[13] ASTM C1240, "Standard specification for silica fume used in cementitious mixtures," in Annual Book of ASTM Standard, 4th ed. vol. 15.02, ASTM Int., United States, 2004, pp. 693 - 699.

[14] ASTM C33, "Standard specification for concrete aggregates," in Annual Book of ASTM Standard, 4th ed. vol. 04.02, ASTM Int., United States, 2003, pp. 12-22.

[15] ASTM C136, "Standard test method for sieve analysis of fine and coarse aggregates," in Annual Book of ASTM Standard, 4th ed. vol. 04.02, ASTM Int., United States, 2010, pp. 100-104.

[16] ASTM C127, "Standard test method for density, relative density (specific gravity), and absorption of coarse aggregate," in Annual Book of ASTM Standard, 7th ed. vol. 04.02, ASTM Int., United States, 2009, pp. 83-88.

[17] ASTM C29, "Bulk density ('unit weight') and voids in aggregate," in Annual Book of ASTM Standard, 9th ed. vol. 04.02, ASTM Int., United States, 2004, pp. 1-5.

[18] ASTM D 4791, "Standard test method for flat particles, elongated particles, or flat and elongated particles in coarse aggregate," in Annual Book of ASTM Standard, 3rd ed. vol. 04.02, ASTM Int., United States, 2011, pp. 6-11.

[19] IS 2386, "Standard methods for aggregates for concrete, part IV mechanical properties, in Indian Standard, 10th ed vol. 4, Bureau of Indian Standards, New Delhi, 2002, pp. 1-37.

[20] ASTM C143, "Standard test method for slump of hydraulic-cement concrete, in Annual Book of ASTM Standard," 3rd ed. vol. 04.02, ASTM Int., United States, 2003, pp. 111-114.

[21] ASTM C138, "Standard test method for density (unit weight), yield and air content (gravimetric)," in Annual Book of ASTM Standard, 3rd ed. vol. 04.02, ASTM Int., United States, 2007, pp. 105 - 108.

[22] BS EN12390, "Testing hardened concrete, part 3: compressive strength of test specimens," in British Standard, Brussels, Belgium, 2009, pp. 1- 22.

[23] ACl E1-99, "Aggregates for concrete," in ACl Education Bulletin, American Concrete Inst., United States of America, 1999, pp. 1-26.

[24] AC1 211.4R-08, "Guide for selecting proportions for high-strength concrete using Portland cement and other cementitious material," 1st ed, American Concrete Institute, United States of America, 2008, pp. 1-29.

[25] ACl 363R, "State-of-the-art report on high-strength concrete,"Reapproved 1997, American Concrete Institute, United States of America, 1997, pp. 1-49.

[26] A. M. Neville, "Properties of Concrete," Dorling Kindersley India Pvt. Ltd., India, 2013.

[27] H. Zhao, C.S. Poon, T.C. Ling, "Utilizing recycled cathode ray tube funnel glass sand as river sand replacement in the high-density concrete," J. Clean. Prod., vol. 51, pp. 184-190, Jan. 2013.

[28] S. Y. Choi, Y. S. Choi, E. I. Yang, "Effects of heavy weight waste glass recycled as fine aggregate on the mechanical properties of mortar specimens," Ann. Nucl. Energy., vol. 99, pp. 372-382, Sept. 2017.

[29] IS 456, "Indian standard: plain and reinforced concrete - code of practice," in Indian Standard, Bureau of Indian Standards, New Delhi, 2000, pp. 1-114.

[30] C. J. Zega, A. Antonio, D. Maio, "Recycled concretes made with waste ready-mix concrete as coarse aggregate," J. Mater. Civ. Eng., vol. 23, pp. 281-286, Mar. 2011. 
[31] S. H. Chen, C. S. Chang, H. Y. Wang, W. L. Huang, "Mixture design of high performance recycled liquid crystal glasses concrete (HPGC),"Constr. Build. Mater., vol. 25, pp. 3886-3892, May 2011.

[32] H. Santos, F. Puertas, S. Martínez-Ramírez, M. Palacios, "Polycarboxylate superplasticiser admixtures: effect on hydration, microstructure and rheological behaviour in cement pastes," Adv. Cem. Res., vol. 17, pp. 77-89, Apr. 2005.

[33] B. Taha, G. Nounu, "Utilizing waste recycled glass as sand/cement replacement in concrete," J. Mater. Civ. Eng., vol. 21, pp. 709-721, Dec. 2009.

[34] A. B. Keryou, G. B. Ibrahim, "Effect of using windows waste glass as coarse aggregate on some properties of concrete," Eng Tech J. vol. 32, pp. 1519-1529, Mar. 2014.

[35] Z. Z. Ismail, E. A. AL-Hashmi, "Recycling of waste glass as a partial replacement for fine aggregate in concrete," Waste Manag., vol. 29, pp. 655-659, Oct. 2009.

[36] N. L. Rahim, R. Che Amat, N. M. Ibrahim, S. Salehuddin, S.A. Mohammed, M. Abdul Rahim, "Utilization of recycled glass waste as partial replacement of fine aggregate in concrete production," Mater. Sci. Forum., vol. 803, pp. 16-20, Jul. 2015.

[37] E. E. Ali, S. H. Al-Tersawy, "Recycled glass as a partial replacement for fine aggregate in self compacting concrete," Constr. Build. Mater., vol. 35, pp. 785-791, Apr. 2012.

[38] P. Dinakar, P.K. Sahoo, G. Sriram, "Effect of metakaolin content on the properties of high strength concrete," Int. J. Concr. Struct. Mater., vol. 7, pp. 215-223, May 2013.

[39] F. E. Amparano, Y. Xi, Y. S. Roh, "Experimental study on the effect of aggregate content on fracture behavior of concrete," Eng. Fract. Mech., vol. 67, pp. 65-84, Mar. 2000.

[40] N. Wongkornchaowalit, V. Lertchirakarn, "Setting time and flowability of accelerated portland cement mixed with polycarboxylate superplasticizer," J. Endod., vol. 37, pp. 387-389, Mar. 2011.

[41] M. Mazloom, A. Hassanloo, Effect of silica fume and superplasticizers on tensile strength of concrete," in Our World Concr. Struct., Singapore, 2009, pp. 360-366.

[42] R. Dubey, P. Kumar, "Effect of superplasticizer dosages on compressive strength of self compacting concrete," Int. J. Civ. Struct. Eng., vol. 3, pp.360-366, Nov. 2012.

[43] A. Kostrzanowska-Siedlarz, J. Gołaszewski, "Rheological properties and the air content in fresh concrete for self compacting high performance concrete," Constr. Build. Mater., vol. 94, pp. 555-564, Jul. 2015.

[44] F. Rajabipour, H. Maraghechi, G. Fischer, "Investigating the alkali-silica reaction of recycled glass aggregates in concrete materials," J. Mater. Civ. Eng., vol. 22, pp. 1201-1208, Dec. 2010.

[45] A. Shayan, A. Xu, "Performance of glass powder as a pozzolanic material in concrete: A field trial on concrete slabs," Cem. Concr. Res., vol. 36, pp. 457-468, Dec. 2006.

[46] T. C. Ling, C. S. Poon "Use of recycled CRT funnel glass as fine aggregate in dry-mixed concrete paving blocks," J. Clean. Prod., vol. 68, pp. 209-215, Jan. 2014.

[47] T. C. Ling, C.S. Poon, "Feasible use of recycled CRT funnel glass as heavyweight fine aggregate in barite concrete," J. Clean. Prod., vol. 33, pp. 42-49, May 2012. 
[48] A. Todhunter, M. Crowley, M. Gholamisheverini, and F. Sartipi, "Advanced technological implementation of construction and demolition waste recycling," Journal of Construction Materials, vol. 1, no. 1, 2019, doi: https://doi.org/10.36756/JCM.v1.1.3.

[49] F. Sartipi, "Automatic sorting of recycled aggregate using image processing and object detection," Journal of Construction Materials, vol. 1, pp. 3-3, 2020, doi: https://doi.org/10.36756/JCM.v1.2.1.

[50] T. Boulos, F. Sartipi, and K. Khoshaba, "Bibliometric analysis on the status quo of robotics in construction," Journal of Construction Materials, vol. 1, pp. 2-3, 2020.

[51] F. Sartipi, "A brief critical view on the carbon-conditioning of recycled aggregate using pressure chamber," Journal of Construction Materials, vol. 2, pp. 1-4, 2020, doi: https://doi.org/10.36756/JCM.v2.1.4.

[52] F. Sartipi and A. Sartipi, "Brief review on advancements in construction additive manufacturing," Journal of Construction Materials, vol. 1, pp. 2-4, 2020, doi: https://doi.org/10.36756/JCM.v1.2.4

[53] A. Gharizadeh, F. Sartipi, E. Ayoubi, and A. Severino, "The chemical reactor design configuration of CO2 concrete green solution," Journal of Construction Materials, vol. 1, pp. 2-5, 2020, doi: https://doi.org/10.36756/JCM.v1.2.5.

[54] A. Todhunter, M. Crowley, and F. Sartipi, "Construction productivity indices in socialism compared with capitalism," Journal of Construction Materials, 2019, doi: https://doi.org/10.36756/JCM.v1.1.2 .

[55] F. Sartipi, "Diffusion of Innovation Theory in the Realm of Environmental Construction," Journal of Construction Materials, vol. 1, pp. 4-2, 2020, doi: https://doi.org/10.36756/JCM.v1.3.2.

[56] F. Sartipi, A. Ghari Zadeh, and M. Gamil, "Electrical resistance of graphene reinforced cement paste," Journal of Construction Materials, 2019.

[57] F. Sartipi, "Feasibility study of concrete recycling in post-disaster reconstruction" Journal of Housing and Rural Environment, vol. 34, 2016.

[58] V. Tam, F. Sartipi, and K. N. Le, "Gaps between supply and demand of recycled aggregate: Sydney metropolitan case study," Presented at the CRIOCM 2018, 2018.

[59] F. Sartipi, "Influence of $5 G$ and IoT in construction and demolition waste recycling-conceptual smart city design," Journal of Construction Materials, vol. 1, pp. 4-1, 2020, doi: https://doi.org/10.36756/JCM.v1.4.1.

[60] F. Sartipi, "Organizational structure of construction entities based on the cooperative game theory," Journal of Construction Materials, vol. 1, no. 2, 2020, doi: https://doi.org/10.36756/JCM.v1.3.3

[61] J. Luliano, A. Singh, and F. Sartipi, "Political-economical evaluation of CO2 capture in Australian building sector," Journal of Construction Materials, vol. 1, pp. 3-2, 2020, doi: https://doi.org/10.36756/JCM.v1.3.2.

[62] F. Sartipi and E. Zarqam, "Recycled concrete and the advantages of using recycled aggregates," presented at the 3rd International congress on architecture, civil engineering and urban development, Tehran, 2016.

[63] M. Gamil, A. Ghari Zadeh, and F. Sartipi, "A review on graphene reinforced cement composite: technical approach for ecofriendly construction," Journal of Construction Materials, 2019.

[64] F. Sartipi and M. Soomro, "Solutions for barriers against the wider use of recycled aggregate." 
[65] M. Sartipi and F. Sartipi, "Stormwater retention using pervious concrete pavement: Great Western Sydney case study," Case Studies in Construction Materials, vol. 11, p. e00274, 2019.

[66] A. Todhunter, M. Crowley, F. Sartipi, and K. Jegendran, "Use of the by-products of post-combustion carbon capture in concrete production: Australian case study," Journal of Construction Materials, vol. 1, no. 1, 2019, doi: https://doi.org/10.36756/JCM.v1.1.1.

[67] F. Sartipi, K. Palaskar, A. Ergin, and U. Rajakaruna, "Viable construction technology for habitation on Mars: Fused Deposition Modelling," Journal of Construction Materials, vol. 1, no. 2, 2020. 